\title{
PERBEDAAN FUNGSI KOGNITIF DAN KORTISOL PADA RESIDEN KEDOKTERAN EMERGENSI DENGAN POLA KERJA SIF
}

\author{
Aurick Yudha Nagara* ${ }^{\star 凶}$, Dwiwardoyo Triyuliarto*, Arief Alamsyah **
}

\begin{abstract}
Abstrak
Kerja sif yang dilakukan pada malam hari atau dengan sistem kerja yang berubah-ubah dapat mengganggu fungsi kognitif dan irama sirkadian. Dokter yang menjalani kerja sif lebih dari 24 jam memiliki risiko lebih tinggi melakukan kesalahan medis akibat penurunan fungsi kognitif. Irama sikardian dapat diketahui dari pola sekresi kortisol. Untuk mengetahui perbedaan pola kerja sif dengan gangguan fungsi kognitif dan kadar kortisol saliva pada residen Kedokteran Emergensi, maka dilakukan penelitian di IGD RSUD Dr. Saiful Anwar Malang pada kurun waktu Juni hingga Juli 2016. Desain penelitian adalah observasional dengan pendekatan potong lintang. Sebanyak tiga puluh residen Kedokteran Emergensi memenuhi kriteria inklusi dan eksklusi dibagi menjadi 2 kelompok, yaitu kelompok kerja sif 12 jam dan kerja sif lebih dari 24 jam. Skala MoCA-Ina digunakan untuk menilai gangguan fungsi kognitif. Cortisol Awakening Response (CAR), total kortisol dan laju penuruan kortisol saliva digunakan untuk mengetahui pola sekresi kortisol. Uji T tidak berpasangan dan Uji Mann Whitney digunakan untuk membedakan kedua kelompok. Didapatkan hasil berupa perbedaan bermakna nilai MoCA-INA antara kelompok kerja sif 12 jam dan kerja sif lebih dari 24 jam $((26,87 \pm 1,69$ vs $24,20 \pm 1,61, p=0,00$, IK $=2,67(1,43-3,90))$. Perbedaan bermakna CAR pada kelompok kerja sif 12 jam dan kerja sif labih dari 24 jam $((14,36(9,88-30,42)$ vs $5,58(1,12-11,15), p=$ $0,00)$ ). Maka, dapat disimpulkan bahwa terdapat perbedaan antara pola kerja sif dengan fungsi kognitif dan kadar kortisol. Kerja sif lebih dari 24 jam dapat menyebabkan gangguan fungsi kognitif dan kadar CAR yang rendah.
\end{abstract}

Kata Kunci: Cortisol Awakening Response (CAR), Instalasi Gawat Darurat (IGD), kerja sif, kognitif.

\section{THE DIFFERENCES BETWEEN COGNITIVE FUNCTION AND CORTISOL IN EMERGENCY MEDICINE RESIDENT WITH SHIFT WORK}

\begin{abstract}
Night shift work or rotating shift work system can affect cognitive and circadian rhythms. Resident doctors who underwent shift work for more than 24 hours had a higher risk of medical errors due to decreased cognitive function. Circadian rhythms can be known from the cortisol secretion pattern. To investigate the differences between shift work with cognitive function and salivary cortisol level between Emergency Medicine (EM) residents, the study was conducted at Emergency Department Saiful Anwar General Hospital Malang during June to July 2016. The research design is observation study with cross sectional approach. Thirty EM residents whomet inclusion and exclusion criteria were divided into 2 groups, they are 12 hours shift workgroup and more than 24 hours shift workgroup. The MoCA-Ina scale is used to assess impaired cognitive function. Cortisol Awakening Response (CAR), total cortisol and salivary cortisol deterioration rate were used to measure cortisol secretion pattern. Unpaired T-test and Mann Whitney test were used to compare between two groups. There was a significant difference in MoCA-INA scores between the 12 hours shift workgroup and more than 24 hours shift workgroup $(26,87 \pm 1,69$ vs. $24,20 \pm$ $1,61, p=0.00, C l=2,67(1,43-3,90))$. A significant difference in CAR levels between the 12 hours shift workgroup and more than 24 hours shift workgroup $((14,36(9,88-30,42)$ vs. $5,58(1,12-11,15), p=0.00))$. There is a differences between shift work with cognitive function and cortisol saliva level. Shift working more than 24 hours can cause impaired cognitive function and low CAR levels.
\end{abstract}

Keywords: cognitive, Cortisol Awakening Response (CAR), emergency department, shift work.

*Departemen IImu Kedokteran Emergensi, Fakultas Kedokteran, Universitas Brawijaya

${ }^{* *}$ Departemen IImu Kesehatan Masyarakat, Fakultas Kedokteran, Universitas Brawijaya

『E-mail: aurickyudha.fk@ub.ac.id 


\section{Pendahuluan}

Banyak industri yang memanfaatkan waktu produksi selama 24 jam setiap harinya untuk mengoptimalisasi hasil produksinya. Untuk dapat mengoptimalisasi 24 jam kerja, perusahaan membuat pengaturan sistem kerja sif bagi pekerjanya. Di negara berkembang, sebanyak $15 \%-20 \%$ penduduk usia kerja bekerja dalam sistem kerja sif. Kerja sif didefinisikan sebagai bentuk sistem kerja yang memiliki jadwal bekerja selain antara pukul 6 pagi hingga 6 malam. ${ }^{1}$

Walaupun kerja sif dapat memaksimalkan hasil produksi, namun hal tersebut tidak sepenuhnya bermanfaat bagi kesehatan dan kesejahteraan pekerjanya. Hampir $60 \%$ pekerja sif mengeluhkan gangguan tidur berupa tidur yang tidak nyenyak dan tidak bisa tidur (insomnia). Pekerja sif malam akan merasakan kelelahan yang lebih berat jika dibandingkan kelelahan yang dirasakan pada saat bekerja siang hari, sedangkan pekerja yang memiliki sif kerja berubah-ubah cenderung mengeluhkan kelelahan yang kronis dibandingkan pekerja yang memiliki jadwal kerja sif tetap. ${ }^{2}$ Kondisi kurang tidur tersebut dapat menyebabkan penurunan tingkat kewaspadaan dan gangguan fungsi kognitif pada pekerja. Fungsi kognitif merupakan suatu proses saat semua masukan sensoris (taktil, visual, auditorik) akan diubah, diolah, disimpan dan selanjutnya digunakan untuk hubungan interneuron secara sempurna sehingga individu mampu melakukan penalaran terhadap masukan sensoris tersebut. Fungsi kognitif mencakup area yaitu: attention (pemusatan perhatian), language (bahasa/ abstraksi), memory (daya ingat), visuospatial (pengenalan ruang), dan executive function (fungsi eksekutif; perencanaan, pengorganisasian dan pelaksanaan). ${ }^{3}$

Gangguan fungsi kognitif yang dialami pekerja sif berkaitan dengan gangguan pada irama sikardian yang berpusat di supra chiasmatic nucleus (SCN) hipotalamus. Irama sikardian yang juga disebut sebagai jam biologis berfungsi mengatur pola harian pada fungsi hormon dan kebiasaan. Hormon yang sangat dipengaruhi oleh irama sikardian adalah hormon kortisol yang diproduksi oleh kelenjar adrenal. Pada pekerja sif terjadi ketidakseimbangan kadar kortisol dalam darah. Jika dibandingkan dengan pekerja yang bekerja di siang hari, maka pekerja sif akan memiliki kadar kortisol yang lebih tinggi di siang hari dan lebih rendah di malam hari. Kondisi tersebut akan berpengaruh terhadap munculnya kelelahan, depresi, obesitas, dan gangguan sif. ${ }^{4}$.

Salah satu industri yang dituntut untuk dapat terus memberikan layanan selama 24 jam adalah industri kesehatan, khususnya rumah sakit. Dokter yang sedang menjalani pendidikan spesialis (residen) juga diharuskan bekerja dalam jam kerja yang panjang untuk meningkatkan kualitas pembelajarannya sesuai dengan peraturan dari Acreditation Council for Graduate Medical Education (ACGME). Kelelahan yang dialami oleh residen yang harus bekerja dalam jam kerja yang panjang bukan hanya berdampak pada kesehatan dan kesejahteraan residen, tetapi juga dapat berdampak pada hasil pelayanan kepada pasien. Dokter yang menjalani pendidikan profesi dengan durasi kerja lebih dari 24 jam setiap sif memiliki risiko lebih tinggi tertusuk benda tajam saat bekerja, risiko lebih tinggi mengalami kecelakaan saat pulang kerja, dan risiko lebih tinggi kesalahan medis baik yang serius maupun fatal dibandingkan saat bekerja dengan durasi waktu 16 jam. ${ }^{5}$

Selama menjalankan proses pendidikan, residen Kedokteran Emergensi harus bekerja dalam jam kerja panjang dengan sistem kerja sif. Terdapat perbedaan jumlah jam kerja, terutama sif malam pada masing-masing jenjang pendidikan di Kedokteran Emergensi. 
Pada bulan Maret 2014 hingga April 2014 jumlah jam kerja residen Kedokteran Emergensi tahun pertama tingkat Basic Specialist Training adalah 66,32 hingga 80,84 jam seminggu, dan untuk residen Kedokteran Emergensi pada tingkat Advance Spesialist Training pada bulan yang sama adalah 49,90 hingga 66,84 jam seminggu. Hasil pengamatan langsung terhadap pelayanan kesehatan yang dilakukan oleh residen Kedokteran Emergensi, pernah didapati adanya satu insiden kesalahan prosedur medis serius. Audit internal yang dilakukan atas kesalahan medis tersebut, disimpulkan akibat kelelahan pada residen. Kesalahan medis dapat terjadi karena meningkatnya kelelahan dan stres pada tenaga kesehatan. ${ }^{6}$ Tingkat kelelahan dan stres pada residen Kedokteran Emergensi yang mengalami sistem kerja sif saat ini belum pernah dievaluasi. Oleh karena itu, perlu diteliti lebih lanjut tentang tingkat kelelahan residen Kedokteran Emergensi yang dengan meneliti kadar dan pola sekresi hormon kortisol dalam saliva, dan fungsi kognitif saat menjalani kerja sif.

\section{Bahan dan Metode}

Desain penelitian adalah observasional dengan pendekatan potong lintang. Pemilihan residen Kedokteran Emergensi sebagai subjek penelitian dilakukan secara acak dari populasi secara sensus. Subjek dikelompokkan menjadi kelompok kerja sif 12 jam dan kerja sif lebih dari 24 jam, kemudian kedua kelompok diukur kadar kortisol saliva dan fungsi kognitifnya.

Kriteria inklusi penelitian adalah Residen Kedokteran Emergensi yang tertulis dalam jadwal sif jaga. Pembagian kerja sif ditentukan Ketua Program Studi setiap awal bulan, berdasarkan tingkatan jenjang pendidikan. Kerja sif 12 jam dilaksanakan pada hari Sabtu dan Minggu, sedangkan kerja sif lebih dari 24 jam dilaksanakan pada hari Senin hingga Jumat. Kriteria eksklusi dilakukan dengan cara anamnesa langsung dengan pertanyaan tertutup. Adapun kriteria eksklusi yang dimaksud adalah: (1). Sedang menjalani pengobatan steroid, (2). Sedang hamil, menyusui, atau mentruasi, (3). Sedang menjalani pengobatan sedatif hipnotik, (4). Riwayat menderita stroke, (5). Menderita penyakit kronis lain yang dikonfirmasi dengan anamnesa langsung, dan (6). Perokok aktif yang dikonfirmasi dengan anamnesa berupa merokok setiap hari untuk jangka waktu minimal 6 bulan dan atau masih merokok saat anamnesa dilakukan.

Variabel bebas pada penelitian ini adalah jenis kerja sif. Variabel tergantung pada penelitian ini adalah fungsi kognitif, sedangkan variabel antara pada penelitian ini adalah kadar kortisol. Definisi operasional dari penelitian ini adalah: (1). Kerja sif, (2). Fungsi kognitif, dan (3). Kadar kortisol. Kerja sif adalah bekerja di luar jam kerja selain jadwal kerja di pagi hari, dimulai setelah pukul 3 sore dengan durasi waktu kerja 8 jam hingga lebih dari 24 jam. Durasi kerja sif dihitung dengan satuan jam, lalu dikategorikan menjadi kerja sif 12 jam dan kerja sif lebih dari 24 jam. Tidak disebut kerja sif bila jam kerja seseorang hanya pada pagi hari saja. Fungsi kognitif adalah kemampuan seseorang yang meliputi daya ingat, perhatian, kewaspadaan dan intelijensi yang mempengaruhi performa dalam bertindak. Fungsi kognitif diukur dengan tes MoCA-Ina yang meliputi fungsi visuospasial, penamaan, atensi, bahasa, abstraksi, recall, dan orientasi. Fungsi kognitif dikatakan terganggu bila nilai tes MoCA-Ina kurang dari 26 poin.

Kadar kortisol saliva adalah kadar hormon kortisol yang diukur dari sampel air liur dengan metode enzyme-linked immunosorbent assay (ELISA). 
Kadar kortisol saliva akan menghasilkan 3 jenis yaitu: (a). Kadar CAR yang dihitung dengan menghitung luas AUC (area under curved) kortisol berdasarkan peningkatan dari nilai dasar (baseline) sesaat setelah bangun tidur (K1) hingga nilai kadar kortisol menit ke30 setelah bangun tidur (K2), (b). Kadar total kortisol yang dihitung dengan cara mengukur AUC seluruh sekresi kortisol (AUC-TOTG) yaitu sekresi kortisol pada menit ke-0 (K1), menit ke-30 (K2) dan jam ke-9 (K3), dan (c). Kadar penuruan kortisol yang dihitung dengan cara menghitung laju penurunan setiap jam dari selisih kadar maksimum kortisol menit ke-30 (K2) dengan kadar kortisol terendah pada hari yang sama pada sekitar jam ke-9 (K3). Pengambilan sampling dilakukan satu hari setelah subjek menjalani kerja sif (keesokan harinya).

Pengambilan sampel kortisol yang dilakukan saat awal bangun tidur memiliki stabilitas nilai tes lebih tinggi bila dibandingkan dengan pengambilan sampel berdasarkan jam tertentu. ${ }^{7}$ Seluruh subjek dilakukan pelatihan mengenai tata cara pengambilan sampel saliva dengan menggunakan cotton roll. Sebelumnya subjek melakukan kumur-kumur terlebih dahulu dengan air bersih, tidak makan besar 1 jam sebelum pengambilan sampel, tidak merokok, dan tidak menggosok gigi selama proses pengambilan sampel berlangsung. Saliva diambil dengan cotton roll dengan cara meletakkannya di bawah lidah selama 5 menit hingga basah. ${ }^{4}$ Pengambilan kadar kortisol dengan menggunakan sampel saliva adalah metode yang tidak invasif, sehingga tidak didapati rasa nyeri pada subjek penelitian. Saliva dimasukkan ke dalam kotak pendingin pada suhu 4-8 ${ }^{\circ} \mathrm{C}$ dan dikirim menuju Laboratorium IImu Faal, Fakultas Kedokteran Universitas Brawijaya, lalu disimpan pada suhu $-80{ }^{\circ} \mathrm{C}$, sebelum dilakukan uji ELISA. Pengukuran kadar kortisol dengan dua pendekatan, yaitu kadar AUC kortisol berdasarkan peningkatan dari nilai dasar (baseline) saat bangun tidur (kortisol AUC$\mathrm{CAR}_{\mathrm{B}}$ ) dan kadar total AUC kortisol dari nilai 0 (ground) (kortisol AUC-TOTG). Cara pengukuran tersebut digunakan untuk mengetahui perbedaan gambaran karakteristik dari CAR. Kortisol AUC-CAR memberikan gambaran perubahan sekresi kortisol selama kurun waktu tertentu yang berhubungan dengan kemampuan reaktifitas. Sedangkan kortisol AUC-TOTG untuk mengukur keseluruhan kortisol yang menggambarkan total pengeluaran kortisol. ${ }^{8}$

Tes fungsi kognitif dilakukan dengan mengisi borang MocA-Ina yang dilakukan pada akhir kerja sif pada masing-masing kelompok yaitu sekitar pukul 19.00 pada kelompok sif kerja 12 jam, dan jam ke-30 (pukul 13.00 keesokan harinya) pada kelompok sif kerja lebih dari 24 jam. Pengambilan nilai MoCA-Ina dilakukan secara blind oleh petugas lain yang telah terlatih. Keterangan laik etik dengan nomor 373/ECl KEPK/09/2016 diperoleh dari Komisi Etik Penelitian Kesehatan Fakultas Kedokteran Universitas Brawijaya. Analisis data diolah dengan perangkat lunak SPSS versi 17 menggunakan uji $\mathrm{T}$ tidak berpasangan dan Uji Mann Whitney.

\section{Hasil}

Dalam kurun waktu 2 bulan pengambilan data, didapatkan jumlah total responden adalah 30 residen Kedokteran Emergensi. Pada bulan pertama penelitian dilakukan pengambilan sampel kortisol saliva dan tes kognitif MocA-Ina. Sebanyak 6 residen Kedokteran Emergensi memenuhi kriteria eksklusi penelitian karena hamil (1 residen), menstruasi (2 residen), perokok aktif (2 residen), dan dengan penyakit kronis (1 residen). Empat residen tidak dapat dilakukan pengambilan data pada bulan pertama karena sedang stase luar. 
Sehingga pada bulan pertama penelitian didapatkan 20 sampel penelitian yang berhasil diambil, dengan pengelompokan 9 residen Kedokteran Emergensi menjalani kerja sif 12 jam, dan 11 residen Kedokteran Emergensi menjalani kerja sif lebih dari 24 jam.

Pada bulan kedua penelitian, 10 orang residen yang drop out saat pengambilan sampel di bulan pertama, kembali ditambahkan dalam sampel penelitian untuk tes fungsi kongnitif tanpa diikuti pengambilan sampel kortisol saliva. Hal ini karena tes fungsi kognitif tidak dipengaruhi oleh perubahan status hormon individu. Sehingga untuk tes fungsi kognitif MoCA-Ina terdapat 30 sampel penelitian. Sebanyak 15 residen menjalani kerja sif 12 jam di pagi hari, dan 15 residen menjalani kerja sif lebih dari 24 jam.

Karakteristik umum keseluruhan residen dapat dilihat pada Tabel 1. Rerata nilai tes fungsi kognitif pada kelompok kerja sif 12 jam adalah $26,87 \pm 1,69$, dan rerata nilai tes fungsi kognitif pada kelompok kerja sif lebih dari 24 jam adalah $24,20 \pm 1,61$. Terdapat perbedaan rerata yang bermakna nilai tes fungsi kognitif pada kedua kelompok kerja sif yang diobservasi dengan nilai $p=0,00$ (Interval Kepercayaan $(\mathrm{IK})=2,67(1,43-3,90)$.

Pada kelompok kerja sif 12 jam, rerata kadar kortisol sesaat setelah bangun tidur sebesar $14,59 \pm 7,45 \mathrm{ng} / \mathrm{ml}$, lalu diikuti peningkatan tajam sebesar $30,22 \pm 6,73 \mathrm{ng} / \mathrm{ml}$, 30 menit setelahnya. Pola peningkatan kadar kortisol saliva secara tajam juga terjadi pada kelompok kerja sif lebih dari 24 jam. Bermula pada kadar 20,51 $\pm 6,56 \mathrm{ng} / \mathrm{ml}$, hingga sebesar $26,45 \pm 6,84 \mathrm{ng} / \mathrm{ml}$ pada saat 30 menit setelah bangun tidur. Hasil rerata pengukuran kadar kortisol saliva 9 jam (540 menit) setelah bangun tidur pada kelompok kerja sif 12 jam dan kelompok kerja sif lebih dari 24 jam secara berurutan adalah $15,87 \pm 12,58 \mathrm{ng} / \mathrm{ml}$ dan $13,36 \pm 5,52 \mathrm{ng} / \mathrm{ml}$.

Tabel 1. Karakteristik umum sampel penelitian berdasarkan observasi kelompok.

\begin{tabular}{|c|c|c|c|c|}
\hline \multicolumn{2}{|c|}{ Karakteristik Sampel Penelitian } & \multirow{2}{*}{$\begin{array}{c}\text { Kerja Sif } \\
12 \text { jam }(n=15) \\
8(26,7 \%) \\
7(23,3 \%)\end{array}$} & \multirow{2}{*}{$\begin{array}{c}\text { Kerja Sif Lebih } \\
\text { Dari } 24 \text { jam (n=15) } \\
7(23,3 \%) \\
8(267 \%)\end{array}$} & \multirow{2}{*}{$\begin{array}{c}\text { Nilai } p \\
p=0,71\end{array}$} \\
\hline Jenis kelamin & $\begin{array}{l}\text { Laki - laki } \\
\text { Perempuan }\end{array}$ & & & \\
\hline Indeks Massa Tubuh & & $24,27 \pm 3,73$ & $24,37 \pm 4,73$ & $p=0,95$ \\
\hline \multirow[t]{4}{*}{ Umur } & & $32,73 \pm 3,71$ & $34,20 \pm 4,26$ & $p=0,32$ \\
\hline & 24-29 tahun & $3(10 \%)$ & $2(6,7 \%)$ & $p=0,375$ \\
\hline & 30-35 tahun & $9(30 \%)$ & $5(16,7 \%)$ & \\
\hline & 36-41 tahun & $3(10 \%)$ & $8(26,7 \%)$ & \\
\hline Tingkatan jaga & Pimpinan Jaga & $5(16,7 \%)$ & $5(16,7 \%)$ & $p=1,00$ \\
\hline \multirow[t]{3}{*}{ Durasi tidur tiap hari } & Jaga II & $3(10 \%)$ & $4(13,3 \%)$ & \\
\hline & Jaga I & $7(23,3 \%)$ & $6(20 \%)$ & \\
\hline & $<6$ jam & $2(6,7 \%)$ & $2(6,7 \%)$ & $p=1,00$ \\
\hline \multirow[t]{4}{*}{ Jam bangun tidur } & 6-8 jam & $13(43,3 \%)$ & $13(43,3 \%)$ & \\
\hline & $>8 \mathrm{jam}$ & 0 & 0 & \\
\hline & $<5.00$ & $2(6,7 \%)$ & $4(13,3 \%)$ & $p=0,99$ \\
\hline & $5.00-5.59$ & $8(26,7 \%)$ & $8(26,7 \%)$ & \\
\hline Durasi napping jika & $6.00-6.59$ & $5(16,7 \%)$ & $3(10 \%)$ & \\
\hline \multirow[t]{5}{*}{ kerja sif > 24 jam } & $>7.00$ & 0 & 0 & \\
\hline & $<60$ menit & $1(3,3 \%)$ & $1(3,3 \%)$ & $p=0,99$ \\
\hline & 61-120 menit & $10(33,3 \%)$ & $12(40 \%)$ & \\
\hline & $121-180$ menit & $3(10 \%)$ & $1(3,3 \%)$ & \\
\hline & $>181$ menit & $1(3,3 \%$ & $1(3,3 \%)$ & \\
\hline
\end{tabular}


Tabel 2. Hasil uji parametrik T tidak berpasangan terhadap kadar kortisol, penurunan kortisol diurnal, kadar total kortisol, dan tes fungsi kognitif MoCA-Ina.

\begin{tabular}{|c|c|c|c|c|c|}
\hline & $\begin{array}{c}\text { Kelompok } \\
\text { Kerja Sif }\end{array}$ & $n$ & $\begin{array}{c}\text { Kadar Kortisol } \\
\text { (ng/ml) }\end{array}$ & $\begin{array}{c}\text { Perbedaan Rerata } \\
\text { (IK 95\%) }\end{array}$ & Nilai $p$ \\
\hline Kortisol & $12 \mathrm{jam}$ & 9 & $14,59 \pm 7,45$ & $5,92(0,79-5,92)$ & 0,80 \\
\hline bangun tidur (K1) & $>24$ jam & 11 & $20,51 \pm 6,56$ & & \\
\hline $\begin{array}{l}\text { Bangun tidur +30 } \\
\text { menit (K2) }\end{array}$ & $\begin{array}{l}12 \mathrm{jam} \\
>24 \mathrm{jam}\end{array}$ & $\begin{array}{l}9 \\
11\end{array}$ & $\begin{array}{l}30,22 \pm 6,73 \\
26,45 \pm 6,84\end{array}$ & $3,77(2,64$ & 0,23 \\
\hline $\begin{array}{l}\text { Bangun tidur }+540 \\
\text { menit (K3) }\end{array}$ & $\begin{array}{l}12 \mathrm{jam} \\
>24 \mathrm{jam}\end{array}$ & $\begin{array}{l}9 \\
11\end{array}$ & $\begin{array}{l}15,87 \pm 12,58 \\
13,36 \pm 5,52\end{array}$ & $2,52(7,47$ & 0,59 \\
\hline $\begin{array}{l}\text { Penurunan kortisol } \\
\text { diurnal, (K1-K3)/jam }\end{array}$ & $\begin{array}{l}12 \text { jam } \\
>24 \text { jam }\end{array}$ & $\begin{array}{l}9 \\
11\end{array}$ & $\begin{array}{l}1,59 \pm 1,18 \\
1,45 \pm 1,08\end{array}$ & $0,13(0,51-0,94)$ & 0,79 \\
\hline $\begin{array}{l}\text { AUC_TOT, } \\
\text { total kortisol } \\
\text { dari ground (nilai 0) }\end{array}$ & $\begin{array}{l}12 \mathrm{jam} \\
>24 \mathrm{jam}\end{array}$ & $\begin{array}{l}9 \\
11\end{array}$ & $\begin{array}{l}10,82 \pm 3,63 \\
10,76 \pm 2,36\end{array}$ & $65,30(2,96-3,10)$ & 0,96 \\
\hline Moca-Ina & $\begin{array}{l}12 \mathrm{jam} \\
>24 \mathrm{jam}\end{array}$ & $\begin{array}{l}15 \\
15\end{array}$ & $\begin{array}{l}\text { Nilai Moca-Ina } \\
26,87 \pm 1,69 \\
24,20 \pm 1,61\end{array}$ & $2,67(1,43-3,90)$ & 0,00 \\
\hline
\end{tabular}

Tabel 3. Hasil uji non parametrik Mann-Whitney terhadap kadar CAR.

\begin{tabular}{llcll}
\hline & $\begin{array}{c}\text { Kelompok } \\
\text { kerja sif }\end{array}$ & $\mathrm{n}$ & $\begin{array}{c}\text { Median } \\
\text { (minimum-maksimum) }\end{array}$ & Nilai p \\
\hline CAR, selisih K2-K1 & 12 jam & 9 & $14,36(9,88-30,42)$ & 0,00 \\
& $>24$ jam & 11 & $5,58(1,12-11,15)$ & \\
AUC_CAR dari & 12 jam & 9 & $215,45(148,18-456,36)$ & 0,00 \\
nilai baseline (K1) & $>24$ jam & 11 & $83,64(16,82-167,27)$ &
\end{tabular}

Pada Tabel 2, menunjukkan bahwa tidak terdapat perbedaan rerata kadar kortisol saliva sesaat setelah bangun tidur (K1) pada kedua kelompok kerja sif yang diobservasi dengan nilai $p=0,80(\mathrm{IK}=5,92(0,79-5,92))$. Rerata kadar kortisol saliva 30 menit setelah bangun tidur (K2) pada kedua kelompok juga tidak terdapat perbedaan bermakna dengan nilai $p=0,23 \quad(\mathrm{IK}=3,77 \quad(2,64-10,20))$. Pengukuran kadar kortisol saliva yang dilakukan 9 jam setelah residen bangun juga tidak terdapat perbedaan yang signifikan pada kedua kelompok kerja sif, dengan hasil nilai $p=0,59(\mathrm{IK}=2,52(7,47-12,50))$.

Pendekatan perhitungan kadar CAR pada penelitian ini dilakukan dengan 2 cara perhitungan, yaitu dengan cara menghitung selisih kenaikan kadar kortisol saliva pada menit-menit awal setelah bangun tidur (K2K1) dan dengan cara menghitung luas area di bawah kurva trapezoid (AUC_CAR), dengan batas bawah dimulai dari kadar kortisol sesaat setelah bangun tidur (K1). Observasi terhadap kelompok sif kerja 12 jam dan kelompok sif kerja lebih dari 24 jam, didapatkan kadar CAR residen emergensi $((14,36(9,88-30,42)$ dan $5,58(1,12-11,15))$ berbeda secara bermakna $(p=0,00)$. Begitu juga kadar AUC_CAR terdapat perbedaan yang bermakna dari kelompok sif kerja 12 jam $(215,45$ (148,18-456,36)) dengan kelompok sif kerja lebih dari 24 jam $(83,64 \quad(16,82-$ 167,27)) (Tabel 3).

\section{Pembahasan}

Perbedaan Pola Kerja Sif dengan Gangguan Fungsi Kognitif

Bekerja dengan sistem kerja sif dapat mengganggu kesehatan tubuh, di antaranya adalah gangguan irama sikardian yang dapat menyebabkan gangguan kualitas tidur. Kondisi kurang tidur dapat menyebabkan penurunan tingkat kewaspadaan dan distorsi fungsi kognitif. ${ }^{9}$ 
Tes fungsi kognitif yang meliputi tes daya ingat, tes perhatian (turunan tes Sternberg), dan tes Weschsler Adult Intelligence Scale. Selain itu, salahsatu alat yang digunakan untuk menilai fungsi kognitif adalah tes Montreal Cognitive Assesment (MoCA) yang dapat mendeteksi gangguan kognitif ringan. ${ }^{10}$ Komponen dari tes MoCA adalah atensi dan konsentrasi, fungsi eksekutif, memori, bahasa, kemampuan visualkonstruksi, pikiran konseptual, kalkulasi, dan orientasi. Nilai maksimal dari penilaian tes MoCa adalah 30 poin. Tes fungsi kognitif MoCA versi Indonesia (MoCA-Ina) juga dinyatakan telah valid menurut kaidah validasi transkultural WHO dan terpercaya, sehingga tes MoCa-Ina dapat digunakan di Indonesia. ${ }^{11}$

Nilai tes MoCA-Ina pada kelompok kerja sif lebih dari 24 jam menunjukkan terjadinya gangguan kognitif ringan. Nilai dari tes $\mathrm{MoCa}$ normal adalah 26-30 poin. ${ }^{10}$ Tes kognitif yang dilakukan pada berbagai profesi yang menjalani kerja sif, menunjukkan penurunan performa daya ingat seiring dengan peningkatan durasi waktu pada kerja sif. Bekerja sif dalam jangka waktu lama akan mengganggu fungsi kognitif yang akan membahayakan bukan hanya individu tersebut, tetapi juga lingkungan kerja. ${ }^{6}$

Kognitif merupakan suatu proses saat semua masukan sensoris (taktil, visual, auditorik) diubah, diolah, disimpan dan selanjutnya digunakan untuk hubungan interneuron secara sempurna, sehingga individu mampu melakukan penalaran terhadap masukan sensoris tersebut. Fungsi kognitif mencakup 5 area yaitu attention (pemusatan perhatian), language (bahasa/ abstraksi), memory (daya ingat), visuospatial (pengenalan ruang), dan executive function (fungsi eksekutif; perencanaan, pengorganisasian dan pelaksanaan). ${ }^{10}$ Penilaian kognitif pada kedua kelompok sif kerja residen Kedokteran Emergensi yang bekerja sif paling bermakna $(p<0,05)$ terjadi pada nilai pengenalan ruang (visuospasial), pemusatan perhatian (atensi) dan abstraksi dengan nilai $p$ masing-masing sebesar $p=$ $0,016, p=0,037$, dan $p=0,034$. Dengan demikian ada perbedaan bermakna antara kelompok sif kerja 12 jam dengan kelompok kerja sif lebih dari 24 jam dari fungsi kognitif domain pengenalan ruang, pemusatan perhatian, dan abstraksi.

Fungsi pengenalan ruang adalah kemampuan konstruksional seperti menggambar atau menirukan berbagai macam gambar (misal: lingkaran, kubus) dan menyusun balok-balok. ${ }^{10}$ Residen Kedokteran Emergensi yang bekerja lebih dari 24 jam mengalami kemunduran dalam fungsi pengenalan ruang pada MoCA-Ina karena tidak mampu menyelusuri jejak secara bergantian (alternating trail making), menggambar kubus, dan menggambar jam dengan benar.

Pemusatan perhatian (atensi) merupakan kemampuan untuk bereaksi atau memperhatikan satu stimulus tertentu dengan kemampuan mengabaikan stimulus lain baik internal maupun eksternal yang tidak dibutuhkan. Residen pada kelompok kerja sif lebih dari 24 mengalami gangguan atensi yang bermakna bila dibanding dengan residen pada kelompok kerja sif 12 jam. Gangguan tersebut diketahui dengan kesalahan menyebutkan angka sesuai perintah dan kesalahan dalam pengurangan berurutan dengan angka 7 saat dilakukan tes. 10 Penelitian tentang hubungan kortisol pagi hari dengan atensi menyatakan bahwa kadar kortisol pagi hari dapat digunakan sebagai prediksi terhadap kemampuan konsentrasi selama sehari. ${ }^{7}$ Kelemahan dalam penelitian ini, belum dicari hubungan antara kadar kortisol pagi hari dengan nilai tes MocaIna, khususnya pada fungsi atensi.

Fungsi abtraksi adalah bagian dari fungsi eksekutif. Fungsi eksekutif merupakan kemampuan kognitif tinggi seperti cara berpikir dan kemampuan pemecahan masalah. 
Pada penelitian ini, residen dengan kerja sif lebih dari 24 jam memiliki nilai fungsi kognisi yang lebih buruk jika dibandingkan dengan residen pada kelompok kerja sif 12 jam. Pada kelompok kerja sif lebih dari 24 jam, adanya gangguan fungsi abtraksi diketahui ketika residen tidak bisa menyebutkan kemiripan antara dua kata yang disebutkan.

\section{Perbedaan Pola Kerja Sif dengan Gangguan Kadar Kortisol \\ Kortisol dapat digunakan sebagai salah} satu marker untuk mengetahui irama sikardian. ${ }^{7}$ Kortisol pada kondisi normal disekresi mengikuti irama siklus sikardian. Pada siklus sikardian normal, jam biologis manusia dimulai pada saat bangun tidur, atau ketika adanya rangsangan cahaya matahari yaitu sekitar jam 6 pagi. Produksi kortisol terbanyak terjadi pada paruh kedua malam hari dengan kadar tertinggi terjadi pada jamjam awal di pagi hari. Kadar tertinggi kortisol pada saat normal tercapai pada jam 8 pagi.4,6,7 Peningkatan kadar kortisol saliva secara tajam terjadi sesaat setelah bangun tidur (K1) sampai 30 menit setelah bangun tidur (K2) pada kedua kelompok residen Kedokteran Emergensi, yang merupakan bentuk respons kebangkitan kortisol terhadap rutinitas tubuh selanjutnya sesuai dalam irama sikardian. Penelitian sebelumnya menyebutkan bahwa peningkatan CAR sebesar $38-75 \%$ dapat dicapai dalam waktu sekitar 30 menit setelah bangun tidur. 4,7 Penelitian ini menunjukkan adanya perbedaan bermakna kadar CAR antara kelompok residen Kedokteran Emergensi yang kerja sif 12 jam dengan kelompok residen Kedokteran Emergensi yang kerja sif lebih dari 24 jam, dengan nilai kebermaknaan $p=0,00$ (Tabel 3). Kadar CAR pada kelompok residen Kedokteran Emergensi yang bekerja sif lebih dari 24 jam adalah 5,58 $(1,12-11,15) \mathrm{ng} / \mathrm{ml}$. Nilai tersebut lebih rendah jika dibandingkan kadar CAR pada kelompok residen Kedokteran Emergensi yang bekerja sif 12 jam, yaitu $14,36(9,88-30,42) \mathrm{ng} / \mathrm{ml}$. Penurunan kadar CAR salah satunya berhubungan dengan rendahnya kualitas tidur. ${ }^{12}$

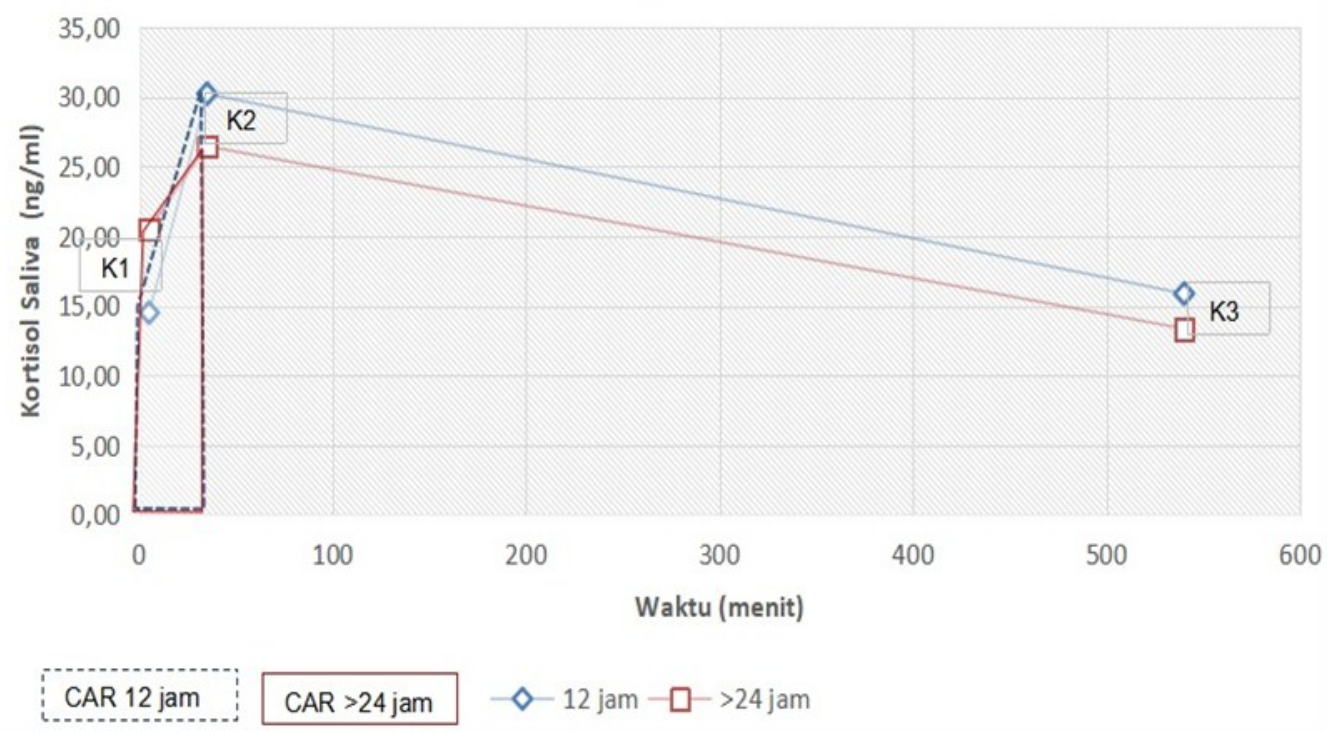

Gambar 1. Grafik sekresi kortisol saliva pada masing-masing kelompok.

Keterangan: (K1) kortisol bangun tidur, (K2) kortisol bangun tidur + 30 menit, (K3) kortisol bangun tidur + 540 menit, CAR merupakan selisih dari K2-K1 atau luas daerah trapezium yang diukur dari nilai 0 (baseline). Tampak pada grafik kadar CAR pada kelompok jaga lebih dari 24 jam (kotak) memiliki nilai yang lebih rendah daripada kadar CAR pada kelompok jaga 12 jam (wajik). 
Tidur merupakan kondisi keadaan tidak sadar yang relatif lebih responsif terhadap rangsangan internal. Fungsi tidur adalah untuk restorasi kembali organ-organ tubuh. Kegiatan restorasi kembali tersebut berbeda pada saat tahap REM dan pada saat fase NREM. Pada saat fase REM akan terjadi pembentukan hubungan baru pada korteks otak dan sistem neuroendokrin yang menuju otak. ${ }^{13}$ Kortisol merupakan mediator neuroendokrin utama yang berfungsi untuk merespons stres dan dapat memberikan gambaran fungsi dari aksis-aksis HPA. ${ }^{12}$ Kelompok residen yang bekerja sif lebih dari 24 jam kemungkinan memiliki kualitas tidur yang lebih buruk dibandingkan dengan kelompok residen dengan kerja sif 12 jam. Kelompok residen dengan kerja sif lebih dari 24 jam hanya melakukan napping dengan durasi terbanyak adalah 61-120 menit (Tabel 1). Dalam 1 siklus tidur terdiri dari 5 tahapan. Keseluruhan tahapan dari tidur kurang lebih membutuhkan waktu selama 90 menit. ${ }^{13}$

Hasil pengukuran kadar kortisol saliva 9 jam (540 menit) setelah bangun tidur pada kelompok residen Kedokteran Emergensi

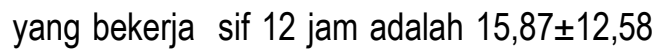
$\mathrm{ng} / \mathrm{ml}$, menurun tajam jika dibandingkan hasil pengukuran kadar kortisol saliva 30 menit setelah bangun tidur, yaitu $30,22 \pm 6,73 \mathrm{ng} / \mathrm{ml}$. Pola penurunan kadar kortisol saliva secara tajam juga terjadi pada kelompok kerja sif lebih dari 24 jam. Bermula pada kadar $26,45 \pm 6,84 \mathrm{ng} / \mathrm{ml}$ pada saat 30 menit setelah bangun tidur hingga terukur $13,36 \pm 5,52 \mathrm{ng} / \mathrm{ml}$ pada waktu pengambilan 9 jam (540 menit) setelah bangun tidur (Gambar 1). Kadar kortisol plasma dapat bervariasi mulai dari 5 $\mu \mathrm{g} / \mathrm{dL}$ hingga $20 \mu \mathrm{g} / \mathrm{dL}$. Pola sekresi tersebut terjadi setiap harinya selama 24 jam dan mengikuti pola tidur dari individu. ${ }^{13}$ Pada irama sikardian normal, saat aktivitas dimulai dengan bangun tidur pada pukul 6 pagi, maka kortisol akan mencapai puncak tertinggi sekitar pukul 8 pagi. Menjelang siang hari, kadar kortisol akan turun secara bertahap. Kadar kortisol terendah akan tercapai pada paruh pertama malam, yaitu pada jam 12 malam. Kortisol adalah hormon yang pola sekresinya melekat pada irama sikardian. Sehingga kortisol dapat digunakan sebagai salah satu marker yang bagus untuk mengetahui irama sikardian. Pengukuran kadar kortisol hanya akan berarti bila diketahui waktu pengambilan sampelnya. $4,7,13$

Hasil penelitian menunjukkan bahwa ada penurunan kortisol diurnal antara kortisol saliva yang diambil pada sesaat setelah bangun tidur (K1) dengan kortisol saliva yang diambil pada 9 jam (540 menit) setelah bangun tidur (K3) pada kedua kelompok residen Kedokteran Emergensi. Pada kelompok residen Kedokteran Emergensi yang bekerja sif 12 jam nilai penurunan kortisol diunal adalah 1,59 $\pm 1,18 \mathrm{ng} / \mathrm{ml}$ (Tabel 2), sedangkan pada kelompok residen Kedokteran Emergensi yang bekerja sif lebih dari 24 jam didapatkan nilai penurunan kortisol diurnal adalah 1,45 $\pm 1,08 \mathrm{ng} / \mathrm{ml}$. Dalam kondisi normal, produksi kortisol terbanyak terjadi pada paruh kedua malam hari dengan kadar tertinggi terjadi pada jamjam awal di pagi hari. Sebaliknya, kadar kortisol akan turun secara bertahap pada siang hari dengan kadar terendah tercapai pada paruh pertama malam hari.7,13 Profil diurnal dari kortisol cenderung tetap pada individu dengan gangguan tidur sehingga kortisol merupakan marker yang bagus untuk mengetahui irama sikardian. Pada individu yang aktif terutama pada siang hari, kadar kortisol terendah terjadi pada sekitar tengah malam dan meningkat secara konstan menjelang akhir tidur. ${ }^{7}$

Nilai perbedaan kebermaknaan (p) antara kedua kelompok pada ketiga waktu pengambilan kortisol saliva (K1, K2, dan $\mathrm{K} 3$ ) masing-masing dengan nilai $p>0,00$. Sehingga tidak didapatkan perbedaan bermakna kadar kortisol saliva antara kedua kelompok. 
Pengaturan jadwal sif kerja residen Kedokteran Emergensi dilakukan setiap bulan. Setiap residen Kedokteran Emergensi akan memperoleh jadwal sif kerja 12 jam dan sif kerja lebih dari 24 jam secara bergantian dalam setiap hari atau setiap minggu Penelitian yang dilakukan Lin et al. (2015), menunjukkan bahwa tidak ada perbedaan profil kortisol antara pekerja yang mengalami pergantian sif kerja pagi/sore/malam secara harian dan pekerja yang mengalami pergantian sif kerja pagi/sore/malam secara mingguan. Hal ini disebabkan karena pada kedua kelompok pekerja yang mengalami perubahan sif harian dan mingguan lebih mudah beradaptasi terhadap perubahan sif kerja yang terjadi secara cepat, sehingga kadar kortisol tetap akan mengikuti irama sikardian.

\section{Kesimpulan}

Terdapat perbedaan pola kerja sif dengan gangguan fungsi kognitif pada residen Kedokteran Emergensi. Gangguan fungsi kognitif terjadi pada area visuospasial, atensi dan abstraksi pada residen Kedokteran Emergensi dengan pola kerja sif lebih dari 24 jam. Selain itu, juga terdapat perbedaan pola kerja sif dengan kadar hormon kortisol saliva pada residen Kedokteran Emergensi, yaitu dengan pola kerja sif lebih dari 24 jam memiliki kadar Cortisol Awakening Response (CAR) lebih rendah.

\section{Saran}

Dapat dilakukan penelitian dengan berbagai variasi waktu kerja sif untuk memperoleh jumlah jam kerja ideal bagi tenaga medis di IGD sehingga tidak menyebabkan gangguan fungsi kognitif. Strategi napping selama kerja sif juga dapat digunakan sebagai variabel lain yang dapat diteliti.

\section{Daftar Pustaka}

1. Wright KP, Bogan RK, Wyatt JK. Shift Work and The Assessment and Management of Shift Work Disorder (SWD). Sleep Medicine Reviews. 2013; 17
(1):41-54.
doi:
$10.1016 /$ j.smrv.2012.02.002.

2. Vallières $A$, Azaiez $A$, Moreau $V$, LeBlanc M, Morin CM. Insomnia in Shift Work. Sleep Med. 2014; 15(12):1440-8. doi: 10.1016/j.sleep.2014.06.021.

3. Özdemir PG, Selvi Y, Özkol H, Aydin A, Tülüce $\mathrm{Y}$, Boysan $\mathrm{M}$, et al. The Influence of Shift Work on Cognitive Functions and Oxidative Stress. Psychiatry Res. 2013; 210(3):1219-25. doi: 10.1016/ j.psychres.2013.09.022.

4. Griefahn B, Robens S. The Normalization of The Cortisol Awakening Response and of The Cortisol Shift Profile Across Consecutive Night Shifts-An Experimental Study. Psychoneuroendocrinology. 2010; 35(10):1501-9. doi: 10.1016/ j.psyneuen.2010.05.002.

5. Peets A, Ayas NT. Restricting Resident Work Hours: The Good, The Bad, And The Ugly. Critical Care Medicine. $2012 ; 40$ (3):960-6. doi: $\quad 10.1097 /$ CCM.0b013e3182413bc5.

6. MacHi MS, Staum M, Callaway CW, Moore C, Jeong K, Suyama J, et al. The Relationship between Shift Work, Sleep, and Cognition in Career Emergency Physicians. Acad Emerg Med. $2012 ; 19$ (1):85-91. doi: 10.1111/j.15532712.2011.01254.x.

7. Lin C-C, Ou K-L, Chu H, Niu S-F, Tsai J$C$, Chung $\mathrm{M}-\mathrm{H}$, et al. Differences in Cortisol Profiles and Circadian Adjustment Time between Nurses Working Night Shifts and Regular Day Shifts: A Prospective Longitudinal Study. Int J Nurs Stud. 2015; 52(7):1193-201. 
8. Wirth M, Burch J, Violanti J, Burchfiel C, Fekedulegn $D$, Andrew $M$, et al. Shiftwork Duration and The Awakening Cortisol Response among Police Officers. Chronobiol Int. 2011; 28(5): 446 $-457$. doi: 10.3109/07420528.2011.573112.

9. Gumenyuk V, Howard R, Roth $T$, Korzyukov O, Drake CL. Sleep Loss, Circadian Mismatch, and Abnormalities in Reorienting of Attention in Night Workers with Shift Work Disorder. Sleep. 2014; 37(3):545-56. doi: 10.5665/ sleep.3494.

10. Julayanont $P$, Nasreddine $Z S$. Montreal Cognitive Assessment (MoCA): Concept and Clinical Review. In: Cognitive Screening Instruments: A Practical Approach. 2016. DOI: 10.1007/978-3319-44775-9_7.
11. Panentu D, Irfan M. Uji Validitas dan Reliabilitas Butir Pemeriksaan dengan Montreal Cognitive Assesment Versi Indonesia (MOCA- INA) pada Insan Pasca Stroke Fase Recovery. J Fisioter. 2013; 13(1):55-67.

12. Niu S-F, Chung M-H, Chen $\mathrm{C}-\mathrm{H}$, Hegney D, O'Brien A, Chou K-R. The Effect of Shift Rotation on Employee Cortisol Profile, Sleep Quality, Fatigue, and Attention Level. J Nurs Res. (Online). 2011; 19(1):68-81. Available from: https://insights.ovid.com/crossref? an=00134372-201103000-00010.

13. Khonsary S. Guyton and Hall: Textbook of Medical Physiology. Surg Neurol Int. (Internet). 2017; 8(1):275. Available from: http://surgicalneurologyint.com/ surgicalint-articles/guyton-and-halltextbook-of-medical-physiology/. 